47 Robinson $\mathrm{P}$, Katon W, Von Korff M, Bush T, Simon G, Lin E, et al. The education of depressed primary care patients: what do patients think of interactive booklets and a video? J Fam Pract 1997; 44: 562-71.

48 Gray JAM. Evidence-Based Healthcare. How to Make Health Policy and Managment Decisions. Churchill Livingstone, 1997.

49 Fydrich $T$, Dowdall $D$, Chambless DL. Reliability and validity of the Beck Anxiety Inventory. J Anxiety Disord 1992; 6: 55-61.

50 Harel $\mathrm{O}$, Zhou XH. Multiple imputation: review of theory, implementation and software. Stat Med 2007; 26: 3057-77.

51 Tang L, Song J, Belin TR, Unutzer J. A comparison of imputation methods in longitudinal randomized clinical trial. Stat Med 2005; 24: 2111-28.

52 Andlin-Sobocki $\mathrm{P}$, Wittchen HU. Cost of anxiety disorders in Europe. Eur J Neurol 2005; 12 (suppl 1): s39-44.
53 Johnston K, Buxton MJ, Jones DR, Fitzpatrick R. Assessing the costs of healthcare technologies in clinical trials. Health Technol Assess 1999: 3: $1-76$.

54 Gold M, Siegel J, Russel L, Weinstein M. Cost-Effectiveness in Health and Medicine. Oxford University Press, 1996.

55 Rasanen $\mathrm{P}$, Roine E, Sintonen H, Semberg-Konttinen V, Ryynanen OP, Roine R. Use of quality-adjusted life years for the estimation of effectiveness of health care: a systematic literature review. Int J Technol Assess Health Care 2006; 22: 235-41.

56 König HH, Roick C, Angermeyer MC. Validity of the EQ-5D in assessing and valuing health status in patients with schizophrenic, schizotypal or delusional disorders. Eur Psychiatry 2007; 22: 177-87.

\title{
Her Kind
}

Poem

\section{Anne Sexton}

I have gone out, a possessed witch, haunting the black air, braver at night; dreaming evil, I have done my hitch

over the plain houses, light by light: lonely thing, twelve-fingered, out of mind A woman like that is not a woman, quite. I have been her kind.

I have found the warm caves in the woods, filled them with skillets, carvings, shelves, closets, silks, innumerable goods; fixed the suppers for the worms and the elves: whining, rearranging the disaligned. A woman like that is misunderstood.

I have been her kind.

I have ridden in your cart, driver, waved my nude arms at villages going by, learning the last bright routes, survivor where your flames still bite my thigh and my ribs crack where your wheels wind A woman like that is not ashamed to die.

I have been her kind.

Anne Sexton, "Her Kind" from The Complete Poems of Anne Sexton (Boston: Houghton Mifflin, 1981). @1981 by Linda Gray Sexton and Loring Conant, Jr. Reprinted with the permission of Sterling Lord Literistic, Inc.

Source: The Complete Poems of Anne Sexton (1981).

Anne Sexton (1928-1974) was an American poet of the Confessional school. Throughout her life she had severe depression and was hospitalised on several occasions. She began writing poetry while recovering after a suicide attempt in 1956, as suggested by her therapist, Dr Martin Orne, and almost instantly won great acclaim - her first book, To Bedlam and Part Way Back (1960), was critically praised and nominated for a National Book Award. Sexton's poetry explored childhood guilt, mental illness, motherhood and female sexuality in a candid and unflinching way (she thought that poetry 'should almost hurt'), and is characterised by musical rhythms and striking imagery. She died by asphyxiating herself.

Poem selected by Kasia Krawczyk.

Another of Anne Sexton's poems was published in the November 2008 issue of the Journal. 